Received: 23 January 2017

Accepted: 31 March 2017

Published online: 10 May 2017

\section{Effect of alkaline microwaving pretreatment on anaerobic digestion and biogas production of swine manure}

Tao $\mathrm{Yu}^{1}$, Yihuan Deng $\mathbb{D}^{2}$, Hongyu $\mathrm{Liu}^{3}$, Chunping Yang $\mathbb{D}^{1,3}$, Bingwen $\mathrm{Wu}^{1}$, Guangming Zeng ${ }^{3}$, Li Lu$^{1}$ \& Fumitake Nishimura ${ }^{4}$

Microwave assisted with alkaline (MW-A) condition was applied in the pretreatment of swine manure, and the effect of the pretreatment on anaerobic treatment and biogas production was evaluated in this study. The two main microwaving (MW) parameters, microwaving power and reaction time, were optimized for the pretreatment. Response surface methodology (RSM) was used to investigate the effect of alkaline microwaving process for manure pretreatment at various values of $\mathrm{pH}$ and energy input. Results showed that the manure disintegration degree was maximized of $63.91 \%$ at energy input of $54 \mathrm{~J} / \mathrm{g}$ and $\mathrm{pH}$ of 12.0, and variance analysis indicated that $\mathrm{pH}$ value played a more important role in the pretreatment than in energy input. Anaerobic digestion results demonstrated that MW-A pretreatment not only significantly increased cumulative biogas production, but also shortened the duration for a stable biogas production rate. Therefore, the alkaline microwaving pretreatment could become an alternative process for effective treatment of swine manure.

Animal manure is one of the major wastes in many agricultural countries due to their intensive animal breeding industry, and it has become a big challenge that should be appropriately treated ${ }^{1}$. The increased and concentrated animal waste generated odour problem and contained pathogen which will threaten people's health if not handled properly. Moreover, it contained nutrients and heavy metals which will impact the quality of surface and ground water if they are discharged directly ${ }^{2}$.

Traditionally, animal manure is treated by anaerobic digestion. The results showed pathogens were destroyed and wastes were stabilized through the process. also, it generated biogas that can be used for daily activities ${ }^{3,4}$. However, the high content of fiber in animal manure was limited the efficiency of anaerobic digestion which cannot be well utilized by anaerobic bacteria ${ }^{5}$. Thus, enhanced biogas production by anaerobic digestion has been paid great attention, and substrate optimization has been focused.

Carlsson et al. ${ }^{6}$ mentioned that pretreatment of manure to break down its structures could be effective for the enhancement of anaerobic digestion. Generally, pretreatment can be roughly divided into three groups, physical pretreatment, chemical pretreatment, and biological pretreatment ${ }^{7}$. Among them, thermo-chemical pretreatment is a main method used in current studies ${ }^{8,9}$. Alkaline is a simpler and easier handling chemical pretreatment method compared with others, especially when combined with thermal effect. Currently, MW pretreatment is a favorable thermal pretreatment method. Compared with traditional heating techniques, MW has the advantages of shorter reaction time and lower energy consumption ${ }^{10}$. Furthermore, microwave pretreatment when combined with other technologies shows better degradation performance ${ }^{11}$.

${ }^{1}$ Zhejiang Provincial Key Laboratory of Solid Waste Treatment and Recycling, College of Environmental Science and Engineering, Zhejiang Gongshang University, Hangzhou, Zhejiang, 310018, P. R. China. ${ }^{2}$ School of Civil and Building Engineering, Loughborough University, Loughborough, Leicestershire, LE11 3TU United Kingdom. ${ }^{3}$ College of Environmental Science and Engineering, Hunan University, Changsha, Hunan, 410082, P. R. China. ${ }^{4}$ Department of Environmental Engineering, Graduate School of Engineering, Kyoto University, C1-2-221, Nishikyo-ku, Kyoto, $615-$ 8540, Japan. Tao Yu, Yihuan Deng and Hongyu Liu contributed equally to this work. Correspondence and requests for materials should be addressed to C.Y. (email: yangcp@zjgsu.edu.cn) or F.N. (email: nishimura.fumitake.3n@ kyoto-u.ac.jp) 


\begin{tabular}{|c|c|c|c|c|c|}
\hline \multirow[b]{2}{*}{ Run } & \multicolumn{2}{|c|}{ Coded variables } & \multicolumn{2}{|c|}{ Experimental variables } & \multirow[b]{2}{*}{ DD (\%) } \\
\hline & $\mathrm{x}_{1}$ & $\mathrm{x}_{2}$ & $x_{1}$ & $\mathrm{x}_{2}(\mathrm{~J} / \mathrm{g})$ & \\
\hline 1 & 0 & 0 & 10 & 54 & 36.40 \\
\hline 2 & -2 & 0 & 8 & 54 & 33.05 \\
\hline 3 & 1 & 1 & 11 & 72 & 54.98 \\
\hline 4 & -1 & 1 & 9 & 72 & 42.34 \\
\hline 5 & 0 & -2 & 10 & 18 & 24.13 \\
\hline 6 & 0 & 0 & 10 & 54 & 33.42 \\
\hline 7 & 2 & 0 & 12 & 54 & 63.91 \\
\hline 8 & 0 & 2 & 10 & 90 & 37.14 \\
\hline 9 & 1 & -1 & 11 & 36 & 45.32 \\
\hline 10 & -1 & -1 & 9 & 36 & 27.11 \\
\hline
\end{tabular}

Table 1. Experiment design matrix for combined Alkaline microwaving pretreatment.

\begin{tabular}{|l|l|l|l|l|l|l|}
\hline Source & Squares & df & Square & Value & Prob $>$ F & \\
\hline Model & 1270.27 & 5 & 254.05 & 11.31 & 0.0178 & significant \\
\hline A- $\mathrm{x}_{1}$ & 714.1 & 1 & 714.1 & 31.79 & 0.0049 & \\
\hline B- $\mathrm{x}_{2}$ & 215.99 & 1 & 215.99 & 9.61 & 0.0362 & \\
\hline $\mathrm{x}_{1} \mathrm{x}_{2}$ & 7.76 & 1 & 7.76 & 0.35 & 0.5884 & \\
\hline $\mathrm{x}_{1}{ }^{2}$ & 151.41 & 1 & 151.41 & 6.74 & 0.0603 & \\
\hline $\mathrm{x}_{2}^{2}$ & 34.43 & 1 & 34.43 & 1.53 & 0.2834 & \\
\hline Lack of Fit & 85.42 & 3 & 28.47 & 6.41 & 0.2807 & not significant \\
\hline $\mathrm{R}^{2}=0.9339$ & & & & & \\
\hline
\end{tabular}

Table 2. ANOVA for a quadratic response surface model.

This study was used microwave as pretreatment under alkaline condition (MW-A). By combination of the two different technologies, the performance of pretreatment was significantly improved ${ }^{12}$, Currently, MW was successful used in activated sludge and anaerobic digestion pretreatment ${ }^{13,14}$. It has great potential to apply in animal manure. However, few research has been reported on MW pretreatment of animal manure. This study was to investigate the mechanism of MW-A by treating animal manure and consider combination effects of microwaving duration, microwave power, and alkaline dosage. Furthermore, this study deeply researched the effects of combining pretreatment of alkaline and microwave on anaerobic digestion at various values of $\mathrm{pH}$ and ammonium nitrogen (AN) concentrations. RSM was involved which is a systematic research strategy for studying the interaction of various parameters effect using statistical methods ${ }^{14}$. The main objective of this study was to evaluate the effect of $\mathrm{pH}$ and energy input on swine manure pretreatment and the effects of $\mathrm{pH}$ and AN concentration on the consequent anaerobic digestion of swine manure with various pretreatment by RSM.

\section{Results}

Optimization for manure pretreatment with RSM. Together with the response values, the complete design matrixes are shown in Table 1 . The highest DD reached $63.91 \%$ in this study. The corresponding second order polynomial fitting equation was as follows:

$$
\mathrm{DD}(\%)=37.88+15.43 x_{1}+8.48 x_{2}-5.57 x_{1}^{2}+12.08 x_{2}^{2}-5.76 x_{1} x_{2}
$$

Whether the model was proper or not was checked by the analysis of variance(ANOVA). The model was calculated by F-value and P-value (Prob $>$ F). When P-value is less than 0.05 which is means that the model is highly significant. The smaller value shows the greater effect ${ }^{15}$. The ANOVA for the quadratic of model for disintegration degree of manure is listed in Table 2. In the study, the P-value of model was less than 0.05 and the Lack of Fit Test was not significant, which indicated that the model had a favorable fitting degree.

Figure 1(a) showed the effect of $\mathrm{pH}$ and energy on DD. The trend of DD of manure was increase to peak and dropped after. The peak of DD was $63.91 \%$ when energy input was $54 \mathrm{~J} / \mathrm{g}$ and $\mathrm{pH}$ was 12 .

In order to investigate model accuracy and practicability, the predicted value and actual value were compared in Fig. 1(b). The maximum experimental DD of manure was $63.91 \%$ while the predicted value was $62.75 \%$, and the absolute error was less than $2 \%$. The correctness and validation of the simulation model is demonstrated.

As a conclusion, the optimum conditions for DD was $54 \mathrm{~J} / \mathrm{g}$ for energy input with stronger alkaline condition $(\mathrm{pH} 12)$.

Changes of $\mathrm{pH}$ on biodegradation. The two groups of manure samples were pretreated by MW with $300 \mathrm{~W}$ power and reaction time of $180 \mathrm{~s}$, which was based on previous conclusion. Figure 2 presented the changes of $\mathrm{pH}$ during the anaerobic digestion.

The results showed that during anaerobic digestion, The MW-A remained weak alkaline environment, while the microwaving pretreatment and control group turn to acidic. 
(a)
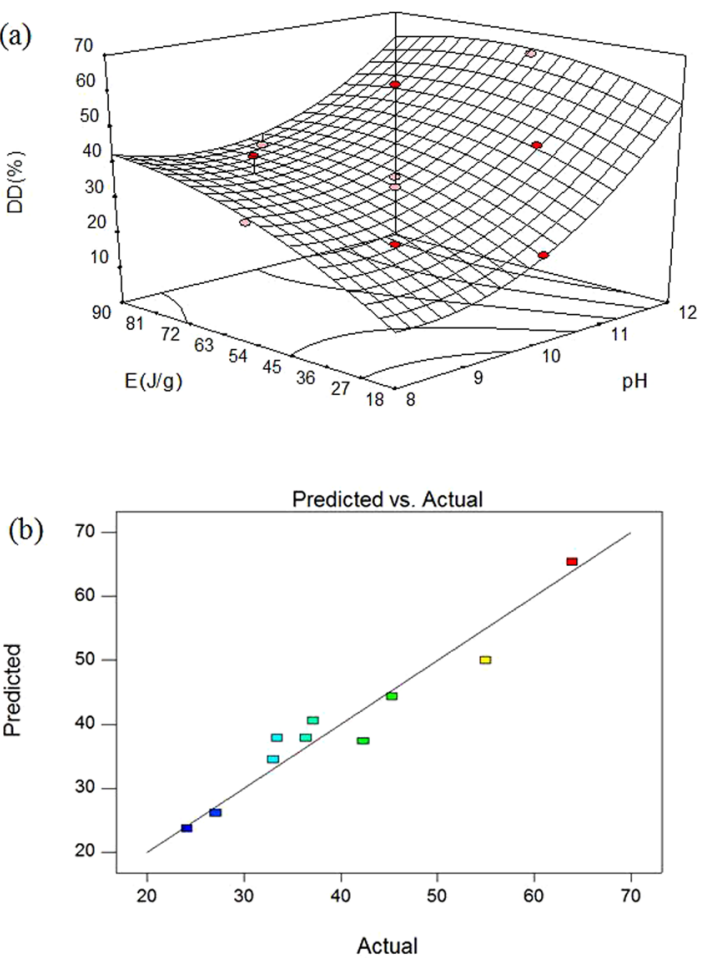

Figure 1. Analysis of Response surface methodology: interactive effects of $\mathrm{pH}$ and $\mathrm{E}$ on DD. (a) 3D response surface; (b) Verification result of RSM predicts and determined.

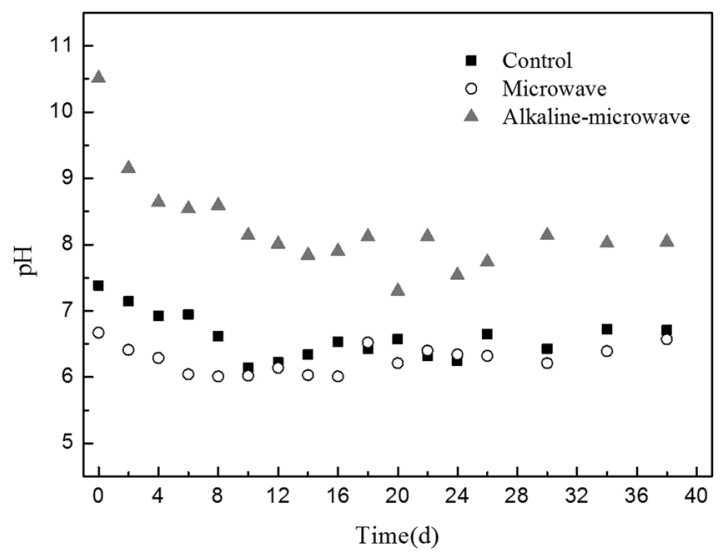

Figure 2. Changes of $\mathrm{pH}$ during the anaerobic digestion after different pretreatments.

Changes of protein concentration on biodegradation. As shown in Fig. 3, after MW pretreatment, the protein concentration was rapidly reduced at the first four day, and then the rate of the degradation decreased 8 days later. The rates were gradually decreased for MW and MW-A groups. The trend of control group was slightly reduced in the whole process, compared others. The protein concentration of MW-A pretreatment was higher than other two groups.

The protein concentration after alkaline microwaving pretreatment remained a relative high level during the whole anaerobic digestion.

Changes of ammonium nitrogen (AN) concentration on biodegradation. The AN concentration during the anaerobic digestion by different pretreatments was recorded and shown in Fig. 4 . As it can be seen in Fig. 4, the content of AN were increased for three groups The MW group was the highest amount of AN concentration, and then in control group, the MW-A group was the lowest one. Figure S2 provided a basis for above changes of $\mathrm{AN}$, and it presented that the dissolution rate of ammonia decreased with the increasing of $\mathrm{pH}$. When $\mathrm{pH}$ was more than 8 , AN density made little change with the increasing of the reaction time. By the stronger alkaline condition, the AN hardly released from manure. 


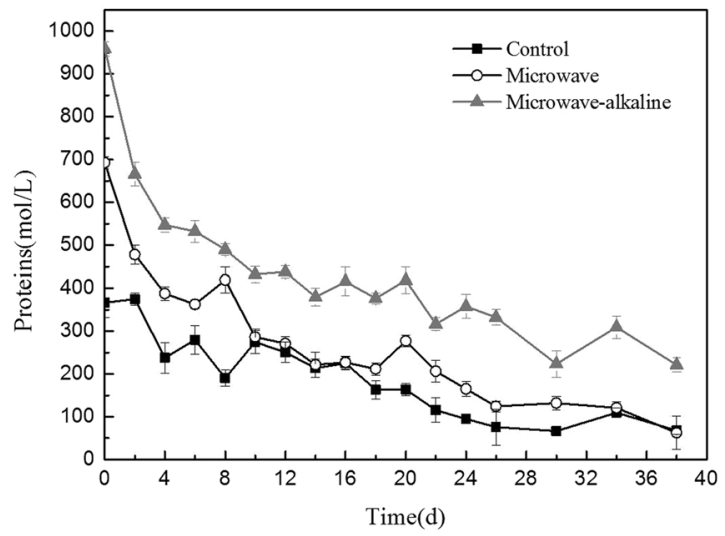

Figure 3. Changes of soluble organics during the anaerobic digestion after different pretreatments.

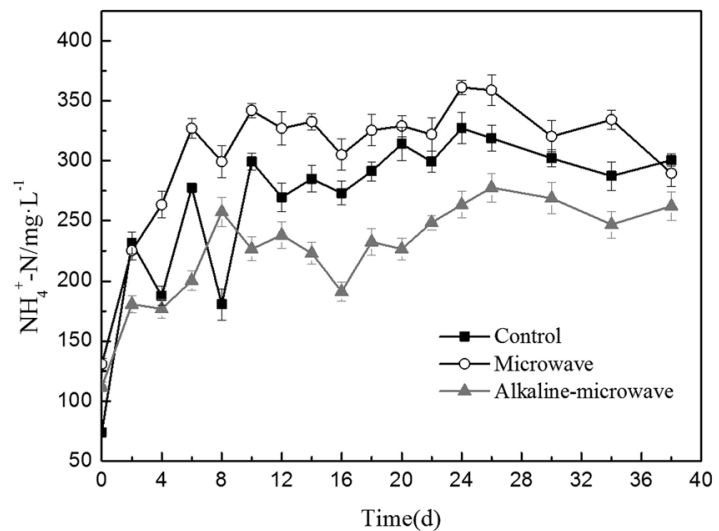

Figure 4. Changes of ammonium nitrogen during the anaerobic digestion after different pretreatments.

Biogas accumulation. Figure 5(a) showed the methane content by anaerobic digestion through different pretreatment. The MW-A group reached 75\%, and others lower around 5\%.

The effect of different pretreatments on total biogas production is shown in Fig. 5(b). The cumulative biogas production was the highest in MW-A pretreatment group, and then in MW only group, and it was the lowest in control group. The biogas production rate for MW-A, MW and control groups began to stabilize in 8 days, 14 days and 14 days, respectively. The daily biogas production after different pretreatments is shown in Fig. 5(c), it showed that there was little biogas production after 16 days, 18 days, 18 days, respectively. So the duration for a stable biogas production rate on three groups was 8 days, 4 days, 4 days, respectively.

The results showed MW-A pretreatment was not only effectively increased the total biogas production, but also shortens the time for a stable biogas production rate.

\section{Discussion}

Table 1 shows that through the MW-A pretreatment, the DD of manure was increased significantly. This could due to microwave radiation break down the complex structure of the polymer substances, and it can make proteins and sugars enter into a soluble phase ${ }^{16}$, meanwhile alkaline effectively solubilize particulate organic matter and improve the digestibility ${ }^{17}$. There was a positive correlation among the DD of manure, the alkaline degree and the energy input.

According to Table 2, $\mathrm{x}_{1}$ and $\mathrm{x}_{2}$ were significant influence factors, which means that $\mathrm{pH}$ and energy could significantly improve the DD of manure. Within the two parameters, $\mathrm{pH}$ was more important than energy input which reported by Doğan and Sanin ${ }^{18}$. The $3 \mathrm{D}$ response surfaces plot also revealed that the DD of manure increased along with enhancing energy input and alkaline degree (see Fig. 1(a)). The results confirmed that the high $\mathrm{pH}$ value was benefit for pretreatment. For example, the energy input remained the same but $\mathrm{pH}$ levels increased from 8 to 12 , the DD rose from $33.05 \%$ to $63.91 \%$. On the contrary, the DD had no significant difference when $\mathrm{pH}$ remaining at 10 and energy input enhanced from $54 \mathrm{~J} / \mathrm{g}$ to $90 \mathrm{~J} / \mathrm{g}$, which got $36.42 \%$ and $37.14 \%$, respectively. The comparison of predicted value and actual value (Fig. 1(b)) also indicated that the alkaline microwaving pretreatment could promote the disintegration degree of manure.

In general, the appropriate $\mathrm{pH}$ is $6.8-7.2$ for completely mixed digesters ${ }^{19}$. Therefore, if the initial $\mathrm{pH}$ was higher than $10(\mathrm{NaOH}$ dose was $0.1 \mathrm{~mol} / \mathrm{L}$ or $0.2 \mathrm{~g} / \mathrm{g} \mathrm{TS})$, the anaerobic digestion process may have been obliterated $^{20}$. In anaerobic digestion process, organic acids were accumulated when the rate of hydrolysis and 

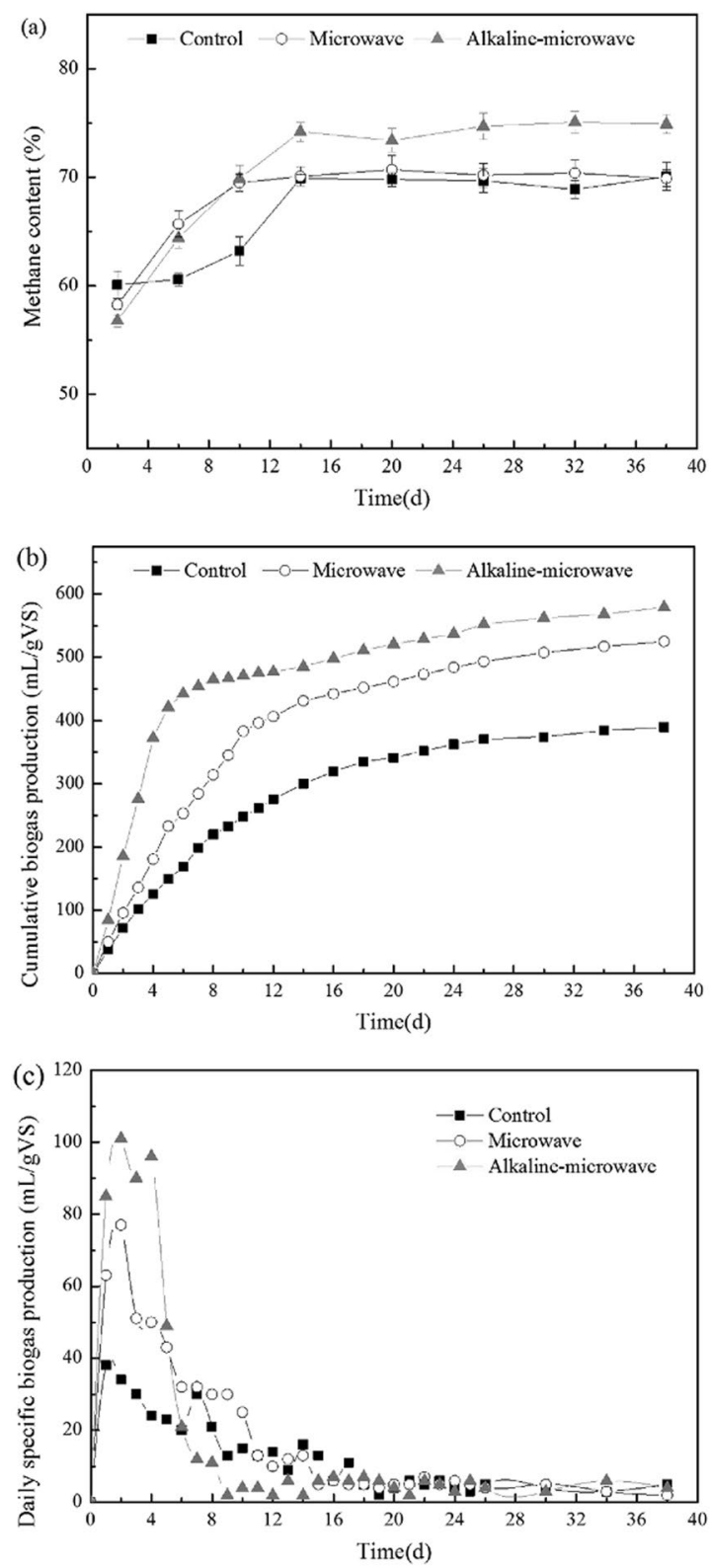

Figure 5. Methane content and cumulative biogas production of manure after different pretreatments. (a) Methane content; (b) Cumulative biogas production; (c) Daily specific production.

acidification stages were over methane-producing stage, and this would cause $\mathrm{pH}$ decline. On the contrary, $\mathrm{pH}$ would enhance when organic acids could not effectively accumulate with similar rate of two stages ${ }^{21}$. Methanogens showed more sensitive to $\mathrm{pH}$ than acid formation bacteria ${ }^{22}$, though few acidophilic methanogens had been found ${ }^{23}$, most of which could only survive in neutral or weak alkaline environment, the accumulation of organic acids in the process of anaerobic digestion would inhibit the growth of methanogens ${ }^{24}$. In Fig. 2, only the combined pretreatment group remained weak alkaline environment for a long time, which implied that methanogens was always the dominant microflora through alkaline-microwave pretreatment group.

The protein is the main constituent of manure, and the manure proteins converted to soluble proteins and in hydrolysis and acidification process, respectively. The soluble organics were mainly produced by microwave effect, and absorbed by acid formation bacteria rapidly ${ }^{25}$. After burning up initial organics, the hydrolysis of manure began to release soluble organic gradually. The protein content of combined alkaline microwaving pretreatment was relatively higher in Fig. 3, which implied that excess acidity alkali promoted manure's hydrolysis ${ }^{26}$.

The AN mainly comes from protein and other nitrogenous organics' degradation:

$$
\begin{aligned}
& \mathrm{RCHNH}_{2} \mathrm{COOH}+2 \mathrm{H}_{2} \mathrm{O} \rightarrow \mathrm{RCOOH}+\mathrm{CO}_{2}+\mathrm{H}_{2}+\mathrm{NH}_{3} \\
& \mathrm{NH}_{3}+\mathrm{H}_{2} \mathrm{O} \rightarrow \mathrm{CO}_{2}+\mathrm{NH}_{4}+\mathrm{HCO}_{3}
\end{aligned}
$$




\begin{tabular}{|l|l|l|l|l|}
\hline $\mathbf{p H}$ & $\begin{array}{l}\text { TCOD } \\
(\mathbf{m g} / \mathbf{g} \text { TS })\end{array}$ & $\begin{array}{l}\text { SCOD } \\
(\mathbf{m g} / \mathbf{g} \text { TS })\end{array}$ & TS(\%) & VS(\%) \\
\hline $7.14 \pm 0.26$ & $208.4 \pm 16.3$ & $50.39 \pm 0.82$ & $6.02 \pm 0.12$ & $4.26 \pm 0.06$ \\
\hline
\end{tabular}

Table 3. Characteristics of swine manure used in this study.

According the results presented in Fig. 4, the pretreatment group's AN density of microwave was greater than the control group, the reason may lie in that there was more protein hydrolysis of AN after pretreatment for microwave. Many earlier studies had investigate that $\mathrm{pH}$ and $\mathrm{AN}$ concentration could affected the methane production ${ }^{27}$. By adjusting $\mathrm{pH}$ to 8.0, a stable digestion of a synthetic acetic acid substrate at inhibitory TAN (total AN concentration) levels of $500 \mathrm{mg} / \mathrm{l}$ was maintained ${ }^{27}$. The high-solids sludge digester could be operated satisfactorily at $\mathrm{pH}$ of 9.0 and $\mathrm{AN}$ concentration of $900 \mathrm{mg} / \mathrm{l}^{28}$. The methane yields in mesophilic Anaerobic Digester were optimum at $\mathrm{pH}$ of 7.9 and $3300 \mathrm{mg}$ TAN/l concentration. However, as TAN went up to $5500 \mathrm{mg} / \mathrm{l}, 50 \%$ reduction in methane production was observed ${ }^{29}$. But few studies showed that the relationship between $\mathrm{pH}$ and AN concentration. Figure S2 presented that the dissolution rate of ammonia decreased with the increasing of $\mathrm{pH}$, so although the protein concentration was the highest after combined pretreatment, because of the weak alkaline environment, which resulted in the low activity of enzymes relative, and the degradation of protein and other nitrogenous organics became more difficult. As a results, the AN content was lower in the digester.

The result of Fig. 5(a) shows that there is a linear correlation between solubilisation and biogas yield ${ }^{30}$, higher energy increases biogas yield even after reaching the boiling point in pretreatment ${ }^{31}$. The disintegration degree of manure was the highest after combining alkaline microwaving pretreatment, the substrate of methanogens was plenty and the hydrolysis rate grew rapidly in the beginning of the anaerobic digestion ${ }^{5}$.

This study showed MW-A group achieved the highest total biogas production than others. The biogas production mainly relies on methanogen. However, the methanogen was inhibited when excess concentration of $\mathrm{AN}$ existed ${ }^{32}$. Even though ammonia is an essential nutrient for bacterial growth, it may inhibit methanogenesis during anaerobic digestion process if it is available at high concentrations ${ }^{27}$. The MW-A pretreatment seemed to improve the recovery speed and stability of an ammonia-inhibited biogas digester fed with cattle manure ${ }^{33}$. The $\mathrm{AN}$ concentration was lower and $\mathrm{pH}$ presented weak alkalinity during anaerobic digestion process, which was suitable for methanogen growth and consequently improved biogas production. This study demonstrated that the MW-A pretreatment improved performance of anaerobic digestion by increasing biogas amount and accelerating the reaction rate.

\section{Methods}

Apparatus. The device of microwave reaction includes the microwave power system, reactor chamber and condenser. The microwave power system whose brand is MY1000S was provided by Huiyan Microwave Corporation (Nanjing, Jiangsu, China). The power of the microwave reaction ranges from 0 to $1000 \mathrm{~W}$. The reaction time was controlled by a timer. The microwave reactor schematic is shown in Fig. S1.

Manure. The swine manure for the experiment was obtained from the rural family swine farms. Fresh manure was smashed and filtered through a $0.45 \mathrm{~mm}$ sizing screen, and then refrigerated at $4^{\circ} \mathrm{C}$ before study. The characteristics of the manure were listed in Table 3.

Microwaving pretreatment. The alkaline microwaving pretreatment for manure disintegration was conducted as follows: The $\mathrm{pH}$ value of $100 \mathrm{ml}$ manure was firstly adjusted to 8.0, 9.0, 10.0, 11.0 and 12.0, respectively, by adding $1.0 \mathrm{M}$ sodium hydroxide $(\mathrm{NaOH})$ or $1.0 \mathrm{M}$ hydrochloric $(\mathrm{HCl})$, and the desired $\mathrm{pH}$ values were kept with \pm 0.1 unit fluctuations. Previous research has shown that the rate of hydrolysis and release rate of protein would arrive at maximum when microwave power reached $300 \mathrm{~W}$, and the earlier study has also reached the same conclusion ${ }^{26}$. So the manure in a quartz reactor was immediately heated in microwave reaction chamber with a microwave power of $300 \mathrm{~W}$. The energy input was set as $18,36,54,72$, or $90 \mathrm{~J} / \mathrm{g}$ by altering the irradiation time. Energy $(\mathrm{E})$ was determined by microwave power $(\mathrm{P})$, microwave time $(\mathrm{t})$, manure solution volume $(\mathrm{V})$, and manure solution volume density $(\rho)$ :

$$
\mathrm{E}(\mathrm{J} / \mathrm{g})=\frac{\mathrm{P} \times \mathrm{t}}{\mathrm{V} \times \rho}
$$

Each sample was analyzed in triplicate, and the average values were determined for each set.

Anaerobic digestion experiment. Anaerobic digestion experiments were conducted in three glass amber bottles. The effective volume of reaction system is $500 \mathrm{~mL}$ each. Every reactor contained a volume of $300 \mathrm{~mL}$ manure. The control group was set by adding untreated manure to one reactor and keeping the $\mathrm{pH}$ value at 7.0. The other two experimental groups were added with manure pretreated by microwave power of $300 \mathrm{~W}$ and reaction time of $180 \mathrm{~s}$, which was based on the result of RSM. One experimental group's $\mathrm{pH}$ value was adjusted to 12.0 by $1 \mathrm{M} \mathrm{NaOH}$ or $1 \mathrm{M}$ hydrochloric $(\mathrm{HCl})$, the other was kept at 7.0. The reactors were placed in Stirring hot plate $\left(100 \mathrm{rpm}, 35 \pm 1{ }^{\circ} \mathrm{C}\right)$ for 40 days, and the gas production was recorded once a day. In order to maintain strict anaerobic condition, oxygen was removed by nitrogen gas sparging before fermentation.

Analysis. Soluble chemical oxygen demand (SCOD), total chemical oxygen demand (TCOD), pH, total solid (TS), and volatile solid (VS) were measured according to the Standard Methods. Soluble protein was determined 
by the Folin phenol method with bovine serum albumin (BSA) as standard ${ }^{34}$. AN was determined by Nessler reagent spectrophotometry ${ }^{35}$. Biogas production was measured with a wet gas meter. Methane was detected by a gas chromatograph (GC7890A, Agilent Technologies, Inc., USA).

Response surface methodology (RSM). RSM is a sensitivity analysis method, which can improve the output of the model and its related input variables. Compared with orthogonal test, RSM can analyze every level of the experiment continuously in the optimization process, while orthogonal test can only study independent data points.

In this study, the experimental design was to combine a central composite design (CCD) with Design-Expert, a software used for data collection and analysis, which was used to research the effect of two independent variables: $\mathrm{pH}$ and energy (E). These two variables' respective ranges were chosen in Table 1.

The target response was the disintegration degree (DD) of manure, which could be calculated by the following formula:

$$
\text { Disintegration degree }(\%)=\frac{\mathrm{SCOD}-\mathrm{SCOD}_{0}}{\mathrm{TCOD}_{0}-\mathrm{SCOD}_{0}} \times 100
$$

where SCOD is the SCOD of the pretreated manure, and SCOD0, TCOD0 is the SCOD, TCOD of the untreated manure, respectively.

The experimental data was fitted by a second-degree polynomial equation:

$$
\mathrm{Y}=\beta_{0}+\beta_{1} x_{1}+\beta_{2} x_{2}+\beta_{11} x_{1}^{2}+\beta_{22} x_{2}^{2}+\beta_{12} x_{1} x_{2}
$$

$\mathrm{Y}$ is the response variable, $\mathrm{x}_{1}$ and $\mathrm{x}_{2}$ are the coded variables. The model prediction is determined by a series of regression coefficient $\beta$, including central point $\beta_{0}$, linear coefficients $\beta_{1}, \beta_{2}$, interaction coefficient $\beta_{11}$ and quadratic coefficients $\beta_{11}, \beta_{22}$.

Ethical statement. This article does not contain any studies with human participants or animals performed by any of the authors.

\section{References}

1. Deng, Y. \& Wheatley, A. Wastewater treatment in Chinese rural areas. Asian Journal of Water. Environment and Pollution 13, 1-11 (2016).

2. Xu, J. L., Adair, C. W. \& Deshusses, M. A. Performance evaluation of a full-scale innovative swine waste-to-energy system. Bioresource Technology 216, 494-502, doi:10.1016/j.biortech.2016.05.089 (2016).

3. Luo, L. et al. Nutrient removal and lipid production by Coelastrella sp. in anaerobically and aerobically treated swine wastewater. Bioresource Technology 216, 135-141, doi:10.1016/j.biortech.2016.05.059 (2016).

4. $\mathrm{Wu}, \mathrm{S}$. H. et al. Effects of $\mathrm{C} / \mathrm{N}$ ratio and bulking agent on speciation of $\mathrm{Zn}$ and $\mathrm{Cu}$ and enzymatic activity during pig manure composting. International Biodeterioration \& Biodegradation (2016).

5. Jin, Y., Hu, Z. \& Wen, Z. Enhancing anaerobic digestibility and phosphorus recovery of dairy manure through microwave-based thermo-chemical pretreatment. Water Research 43, 3493-3502, doi:10.1016/j.watres.2009.05.017 (2009).

6. Carlsson, M., Lagerkvist, A. \& Morgan-Sagastume, F. The effects of substrate pre-treatment on anaerobic digestion systems: a review. Waste Management 32, 1634-1650, doi:10.1016/j.wasman.2012.04.016 (2012).

7. Wen, S. et al. Treatment of anaerobically digested swine wastewater by Rhodobacterblasticus and Rhodobactercapsulatus. Bioresource Technology 222, 33-38, doi:10.1016/j.biortech.2016.09.102 (2016).

8. Guo, J. Y., Yang, C. P. \& Peng, L. Y. Preparation and characteristics of bacterial polymer using pre-treated sludge from swine wastewater treatment plant. Bioresource Technology 152, 490-498, doi:10.1016/j.biortech.2013.11.037 (2014).

9. Guo, J. Y., Yang, C. P. \& Zeng, G. M. Treatment of swine wastewater using chemically modified zeolite and bioflocculant from activated sludge. Bioresource Technology 143, 289-297, doi:10.1016/j.biortech.2013.06.003 (2013).

10. Motevali, A. et al. M. H. Comparison of energy parameters in various dryers. Energy Conversion and Management 87, 711-725, doi:10.1016/j.enconman.2014.07.012 (2014).

11. Yeneneh, A. M., Kayaalp, A., Sen, T. K. \& Ang, H. M. Effect of microwave and combined microwave-ultrasonic pretreatment on anaerobic digestion of mixed real sludge. Journal of Environmental Chemical Engineering 3, 2514-2521, doi:10.1016/j. jece.2015.09.003 (2015).

12. Cheng, X. Y. \& Liu, C. Z. Enhanced biogas production from herbal-extraction process residues by microwave-assisted alkaline pretreatment. Journal of Chemical Technology and Biotechnology 85, 127-131, doi:10.1002/jctb.v85:1 (2010).

13. Ebenezer, A. V. et al. Effect of deflocculation on the efficiency of low-energy microwave pretreatment and anaerobic biodegradation of waste activated sludge. Applied Energy 145, 104-110, doi:10.1016/j.apenergy.2015.01.133 (2015).

14. Yang, C. P. et al. Catalytic oxidative desulfurization of gasoline using catalyst of molybdenum supported on 4A molecular sieve. Separation and Purification Technology 163, 153-161, doi:10.1016/j.seppur.2016.02.050 (2016).

15. Li, C. L. et al. Kinetics model for combined (alkaline+ultrasonic) sludge disintegration. Bioresource Technology 101, 8555-8557, doi:10.1016/j.biortech.2010.06.056 (2010).

16. Eskicioglu, C., Kennedy, K. J. \& Droste, R. L. Characterization of soluble organic matter of waste activated sludge before and after thermal pretreatment. Water Research 40, 3725-3736, doi:10.1016/j.watres.2006.08.017 (2006).

17. Li, X. J., Zhang, R. H. \& Pang, Y. Z. Characteristics of dairy manure composting with rice straw. Bioresource Technology 99, 359-367, doi:10.1016/j.biortech.2006.12.009 (2008).

18. Doğan, I. \& Sanin, F. D. Alkaline solubilization and microwave irradiation as a combined sludge disintegration and minimization method. Water Research 43, 2139-2148, doi:10.1016/j.watres.2009.02.023 (2009).

19. Lay, J. J. et al. Analysis of environmental factors affecting methane production from high-solids organic waste. Water Science and Technology 36, 493-500, doi:10.1016/S0273-1223(97)00560-X (1997).

20. Li, H., Li, C., Liu, W. \& Zou, S. Optimized alkaline pretreatment of sludge before anaerobic digestion. Bioresource Technology 123, 189-194, doi:10.1289/ehp.1103934 (2012).

21. Kang, X. R. et al. Effect of initial pH adjustment on hydrolysis and acidification of sludge by ultrasonic pretreatment. Industrial \& Engineering Chemistry Research 50, 12372-12378 (2011).

22. Garcia, J. L., Patel, B. K. \& Ollivier, B. Taxonomic, phylogenetic, and ecological diversity of methanogenic Archaea. Anaerobe 6, 205-226, doi:10.1006/anae.2000.0345 (2000). 
23. Bräuer, S. L. et al. Characterization of acid-tolerant $\mathrm{H}_{2} / \mathrm{CO}_{2}$-utilizing methanogenic enrichment cultures from an acidic peat bog in New York State. FEMS Microbiology Ecology 57, 206-216, doi:10.1111/j.1574-6941.2006.00107.x (2006).

24. Chen, Y., Cheng, J. J. \& Creamer, K. S. Inhibition of anaerobic digestion process: a review. Bioresource Technology 99, 4044-4064, doi:10.1016/j.biortech.2007.01.057 (2008).

25. Hu, Z. \& Wen, Z. Enhancing enzymatic digestibility of switchgrass by microwave-assisted alkali pretreatment. Biochemical Engineering Journal 38, 369-378, doi:10.1016/j.bej.2007.08.001 (2008).

26. Yang, Q. et al. Improving disintegration and acidification of waste activated sludge by combined alkaline and microwave pretreatment. Process Safety and Environmental Protection 91, 521-526, doi:10.1016/j.psep.2012.12.003 (2013).

27. Yenigün, O. \& Demirel, B. Ammonia inhibition in anaerobic digestion: a review. Process Biochemistry 48, 901-911, doi:10.1016/j. procbio.2013.04.012 (2013).

28. Lay, J. J., Li, Y. Y. \& Noike, T. The influence of $\mathrm{pH}$ and ammonia concentration on the methane production in high-solids digestion processes. Water Environment Research 70, 1075-1082, doi:10.2175/106143098X123426 (1998).

29. Westerholm, M., Müller, B., Arthurson, V. \& Schnürer, A. Changes in the acetogenic population in a mesophilic anaerobic digester in response to increasing ammonia concentration. Microbes and Environments 26, 347-353, doi:10.1264/jsme2.ME11123 (2011).

30. Passos, F., Solé, M., García, J. \& Ferrer, I. Biogas production from microalgae grown in wastewater: effect of microwave pretreatment. Applied Energy 108, 168-175, doi:10.1016/j.apenergy.2013.02.042 (2013).

31. Sólyom, K., Mato, R. B., Pérez-Elvira, S. I. \& Cocero, M. J. The influence of the energy absorbed from microwave pretreatment on biogas production from secondary wastewater sludge. Bioresource Technology 102, 10849-10854, doi:10.1016/j.biortech.2011.09.052 (2011).

32. Rajagopal, R., Massé, D. I. \& Singh, G. A critical review on inhibition of anaerobic digestion process by excess ammonia. Bioresource Technology 143, 632-641, doi:10.1016/j.biortech.2013.06.030 (2013).

33. Nielsen, H. B. \& Ahring, B. K. Effect of tryptone and ammonia on the biogas process in continuously stirred tank reactors treating cattle manure. Environmental Technology 28, 905-914, doi:10.1080/095933328086188485 (2007).

34. Lowry, O. H., Rosebrough, N. J., Farr, A. L. \& Randall, R. J. Protein measurement with the Folin phenol reagent. J BiolChem 193, 265-275 (1951).

35. Krug, F., Růžička, J. \& Hansen, E. Determination of ammonia in low concentrations with Nessler's reagent by flow injection analysis. Analyst 104, 47-54, doi:10.1039/an9790400047 (1979).

\section{Acknowledgements}

This research was supported by the International S\&T Cooperation Program of China under Project Contract No. 2015DFG92750), the Zhejiang Provincial Natural Science Foundation of China under Grant No. LY17E080002, the National Natural Science Foundation of China under Grant Nos 51278464 and 51478172), and the Department of Science and Technology of Hunan Province (Project Contract No.: 2014GK1012).

\section{Author Contributions}

Tao Yu, Yihuan Deng, Chunping Yang, Li Lu and Fumitake Nishimura wrote the manuscript, Tao Yu and Bingwen Wu prepared Figures 1-5. Tao Yu, and Hongyu Liu prepared Tables 1-3. All authors developed the experimental plan and edited this manuscript.

\section{Additional Information}

Supplementary information accompanies this paper at doi:10.1038/s41598-017-01706-3

Competing Interests: The authors declare that they have no competing interests.

Publisher's note: Springer Nature remains neutral with regard to jurisdictional claims in published maps and institutional affiliations.

Open Access This article is licensed under a Creative Commons Attribution 4.0 International License, which permits use, sharing, adaptation, distribution and reproduction in any medium or format, as long as you give appropriate credit to the original author(s) and the source, provide a link to the Creative Commons license, and indicate if changes were made. The images or other third party material in this article are included in the article's Creative Commons license, unless indicated otherwise in a credit line to the material. If material is not included in the article's Creative Commons license and your intended use is not permitted by statutory regulation or exceeds the permitted use, you will need to obtain permission directly from the copyright holder. To view a copy of this license, visit http://creativecommons.org/licenses/by/4.0/.

(c) The Author(s) 2017 